\title{
EPIDEMIOLOGICAL SITUATION OF LYME BORRELIOSIS IN THE POLISH-BELARUSIAN BORDERLAND IN THE YEARS 2012-2016 (PODLASIE PROVINCE AND GRODNO REGION)
}

\section{SYTUACJA EPIDEMIOLOGICZNA BORELIOZY Z LYME NA TERENIE POGRANICZA POLSKO-BIALORUSKIEGO W LATACH 2012-2016 (WOJEWÓDZTWO PODLASKIE I OBWÓD GRODZIEŃSKI)}

\author{
Aleksandra Leonidovna Sovkich ${ }^{1(A, B, C, D, E, F)}$, Anna Pańczuk ${ }^{2(A, B, C, D, E, F)}$, \\ Maria Kozioł-Montewka ${ }^{3(\mathrm{~A}, \mathrm{~B}, \mathrm{D}, \mathrm{E})}$, Vladimir Maksimovich Tsyrkunov ${ }^{1(\mathrm{~A}, \mathrm{D}, \mathrm{F})}$, \\ Małgorzata Tokarska-Rodak ${ }^{3(\mathrm{~A}, \mathrm{E})}$, Alla Richardovna Hutko ${ }^{4(\mathrm{~A}, \mathrm{C})}$ \\ ${ }^{1}$ Department of Infectious Diseases, Grodno State Medical University, Belarus \\ ${ }^{2}$ Institute of Physical Education and Physiotherapy, Pope John Paul II State School of Higher Education \\ in Biała Podlaska, Poland \\ ${ }^{3}$ Institute of Health Sciences, Pope John Paul II State School of Higher Education in Biała Podlaska, Poland \\ ${ }^{4}$ Grodno Regional Center of Hygiene, Epidemiology and Public Health, Belarus
}

Authors' contribution Wkład autorów: A. Study design/planning zaplanowanie badań B. Data collection/entry zebranie danych C. Data analysis/statistics dane - analiza i statystyki D. Data interpretation interpretacja danych E. Preparation of manuscript przygotowanie artykułu F. Literature analysis/search wyszukiwanie i analiza literatury G. Funds collection zebranie funduszy
Tables: 4

Figures: 5

References: 22

Submitted: 2017 Jun 07

Accepted: 2017 Jun 22

\section{Summary}

Lyme borreliosis (LB) is the most common tick-borne disease in Europe and the number of reported cases is constantly rising. An increase in morbidity can be observed both in Poland and Belarus; however, the recorded rates are much higher in Poland. The aim of the article was to analyze the epidemiological situation of Lyme borrelosis in neighbouring territories in the Polish-Belarusian borderland: Grodno Region and Podlasie Province in the years 2012-2016. Differences in the recorded incidence of Lyme borreliosis in the analyzed territories were higher than those noted as national indicators in each consecutive year of the analyzed fiveyear period. In 2016, the incidence rate in Grodno Region was 25.0/100,000 inhabitants, while in Podlasie Province it was over 5 times higher (134.9/100,000 inhabitants). A detailed analysis of the rates in particular districts of the analyzed territories showed that the areas in Podlasie Province directly adjacent to Grodno Region are characterized by high Lyme borreliosis incidence rates, whereas those in Grodno Region bordering with Podlasie Province generally recorded rates close to the indicator for the whole region. Understanding the big differences in the recorded incidence of LB in the neighbouring Polish-Belarusian border areas requires further detailed analyses in order to identify the factors influencing such a situation.

Keywords: Lyme borreliosis, epidemiology, borderland, Poland, Belarus

\section{Streszczenie}

Borelioza z Lyme (LB) jest najczęściej rejestrowaną chorobą odkleszczową w Europie i liczba zgłaszanych zachorowań stale rośnie. Zarówno w Polsce, jak i Białorusi obserwujemy wzrost zachorowań; rejestrowane współczynniki zapadalności są jednak wyraźnie wyższe w Polsce. Celem artykułu była analiza sytuacji epidemiologicznej boreliozy z Lyme w sąsiadujących ze sobą regionach na terenie pogranicza polsko-białoruskiego: obwodzie grodzieńskim i województwie podlaskim, w latach 2012-2016. W analizowanych regionach, różnice $\mathrm{w}$ rejestrowanej zapadalności na borelioze z Lyme okazały się jeszcze większe, aniżeli w odniesieniu do wskaźników krajowych w każdym z pięciu analizowanych lat. W roku 2016 wskaźnik zapadalności na boreliozę z Lyme w obwodzie grodzieńskim wyniósł 25,0/100 tys. mieszkańców, podczas gdy w województwie podlaskim był ponad 5-krotnie wyższy $(134,9 / 100$ tys. mieszkańców). Szczegółowa analiza wskaźników zapadalności w poszczególnych powiatach i rejonach analizowanych regionów wykazała, iż w województwie podlaskim, powiaty bezpośrednio graniczące $\mathrm{z}$ obwodem grodzieńskim charakteryzują się wysokimi wskaźnikami zapadalności na boreliozę z Lyme, podczas gdy rejony obwodu grodzieńskiego graniczące z województwem podlaskim z reguły rejestrowały wskaźniki zapadalności zbliżone do ogólnego wskaźnika w obwodzie grodzieńskim. Bardzo duże zróżnicowanie w rejestrowanej zapadalności na LB w sąsiadujących rejonach pogranicza polsko-białoruskiego, skłaniają do dalszej szczegółowej analizy celem wyłonienia czynników wpływających na taką sytuację.

Słowa kluczowe: borelioza z Lyme, epidemiologia, pogranicze, Polska, Białoruś

Sovkich AL, Pańczuk A, Kozioł-Montewka M, Tsyrkunov VM, Tokarska-Rodak M, Hutko AR. Epidemiological situation of Lyme borreliosis in the Polish-Belarusian borderland in the years 2012-2016 (Podlasie Province and Grodno Region). Health Problems of Civilization. 2017; 11(2): 71-79. doi: 10.5114/hpc.2017.69021.

Address for correspondence / Adres korespondencyjny: Anna Pańczuk, Pope John Paul II State School of Higher Education in Biała Podlaska, Sidorska 95/97, Address for correspondence / Adres korespondencyjny: Anna Panczuk, Pope John Paul II State
21-500 Biała Podlaska, Poland, e-mail: anna.panczuk@poczta.onet.pl, phone +48 833449900

Copyright: (c) 2017 Pope John Paul II State School of Higher Education in Biała Podlaska, Aleksandra Leonidovna Sovkich, Anna Pańczuk, Maria Kozioł-Montewka, Vladimir Maksimovich Tsyrkunov, Małgorzata Tokarska-Rodak, Alla Richardovna Hutko. This is an Open Access journal, all articles are distributed under the terms of the Creative Commons Attribution-NonCommercial-ShareAlike 4.0 International (CC BY-NC-SA 4.0) License (http://creativecommons.org/licenses/by-nc$\mathrm{sa} / 4.0 /$, allowing third parties to copy and redistribute the material in any medium or format and to remix, transform, and build upon the material, provided the original work is properly cited and states its license. 


\section{Introduction}

Lyme disease, Lyme borreliosis (LB) is the most common vector-borne disease in the WHO European Region and number of its cases in Europe has increased steadily [1]. In addition to the increase in the incidence of the disease, most geographical areas in Europe have also recorded territorial expansion in the areas where it occurs [2,3]. The causes of such a situation are multifaceted. The spread of Borrelia burgdorferi spirochetes (the etiological agents of LB) results from a large range of habitats of ticks, which are vectors of the pathogens. The major role in ticks expansion is attributed to migrant hosts, mainly birds, which are responsible for the spread of these arachnids. The occurrence of ticks in new habitats is also the result of the climate and land use change $[2,3,4]$. The changes in land use that are conducive to the development of ticks population include, in particular, the conversion of farmland into fallow and forest areas [5]. Another important factor influencing an increase in Lyme borreliosis can be linked to the popularity of active outdoor activities and tourism, which are often associated with the people penetrating rarely visited ecosystems $[6,7,8]$. Finally, the increase in the number of the registered diseases is undoubtedly influenced by improved diagnostic methods as well as increased public and medical staff awareness [3].

Different criteria are taken into account in the clinical diagnosis of Lyme borreliosis in different European countries, which prevents a clear epidemiological assessment in the continent. Further, many cases remain undiagnosed and there also appears a problem of over-diagnosis $[2,3,6,8]$.

Lyme borreliosis is more common in Central and Eastern Europe than in the western part. This disease is clearly less common on the northern and southern outskirts of the continent. Likewise, there is less morbidity in the north of Scandinavia than in its southern part, which is also true of southern Italy, Spain and Greece when compared to the northern parts of these countries [1].

Both in Poland and Belarus there has been observed an increase in the recorded cases of LB. However, in Poland the rate of morbidity has shown a bigger growth and the figures are also higher. In the last five years (2012-2016), this indicator increased from 22.8 to 55.2/100,000 inhabitants, while in Belarus it has grown from 11.6 to 19.7/100,000 inhabitants [9,10]. The detailed epidemiological data for both countries are provided in Fig. 1 and Fig. 2.

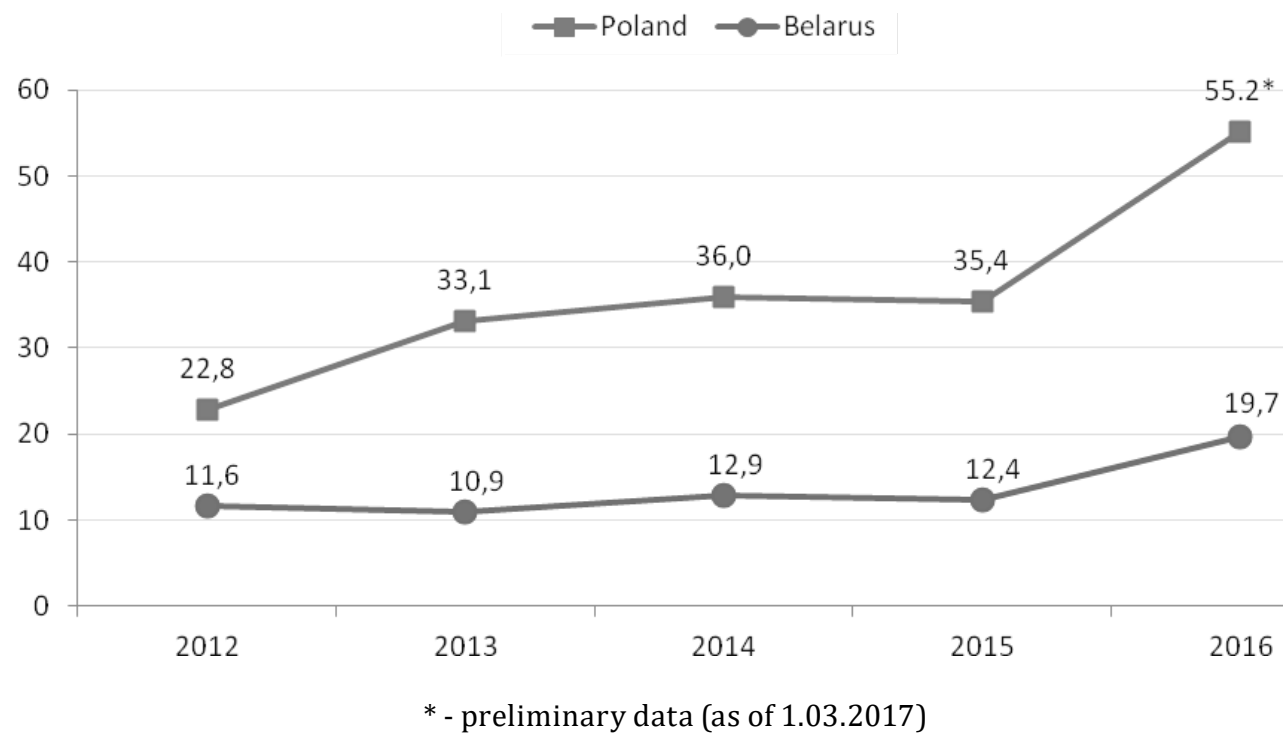

Figure 1. Lyme borreliosis incidence rate in Poland and Belarus in 2012-2016 [9,10] 


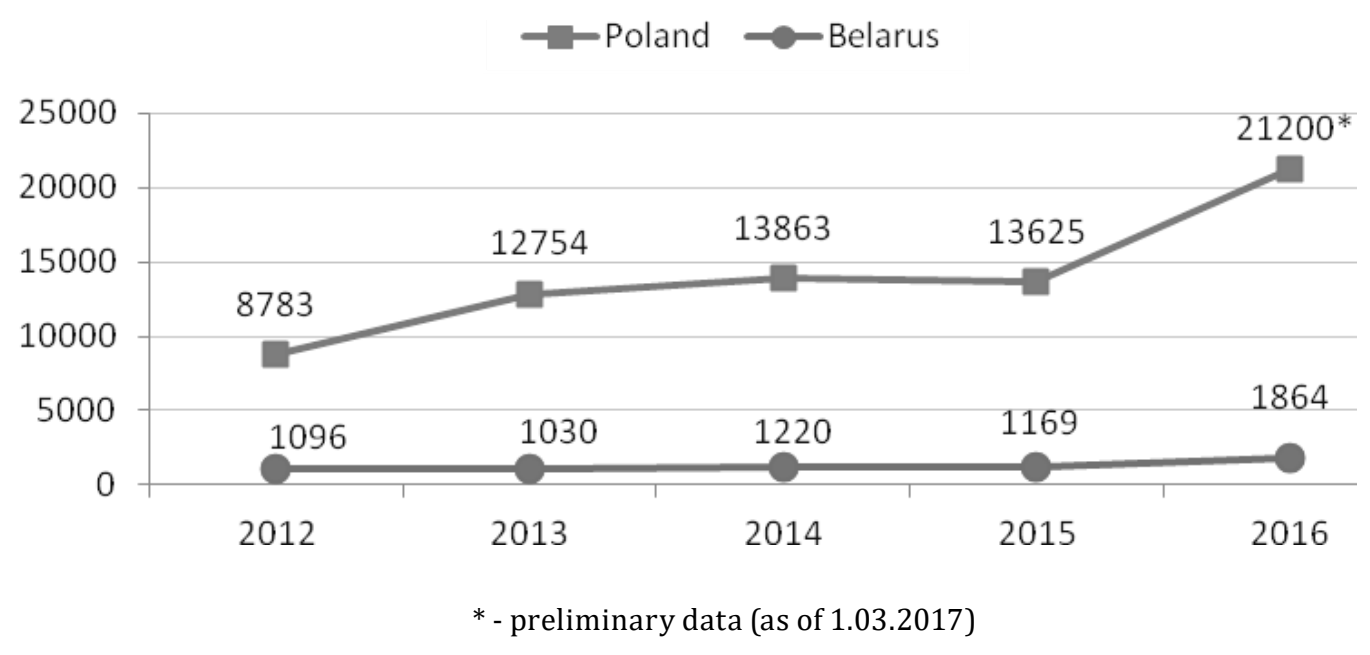

Figure 2. Number of cases of Lyme borreliosis in Poland and Belarus in 2012-2016 [9,10]

\section{Aim of study}

The aim of the article was to analyze the epidemiological situation of Lyme borrelosis in neighbouring territories on the Polish-Belarusian border: Podlasie Province and Grodno Region in the years 2012-2016.

\section{Study area}

The Podlasie Province is located in the north-eastern part of Poland, whereas Grodno Region in the northwestern part of Belarus (Fig. 3). According to the administrative division, Grodno Region includes 17 districts and 1 city with district rights. Out of these, Poland borders directly with 3 districts, i.e. Grodno, Berestovitsa, and Svisloch. In Podlasie Province, there are 14 districts and 3 cities with district rights, out of which 4 districts border with Grodno Region directly in the north. These include: Augustów, Sokółka, Białystok and Hajnowka districts.

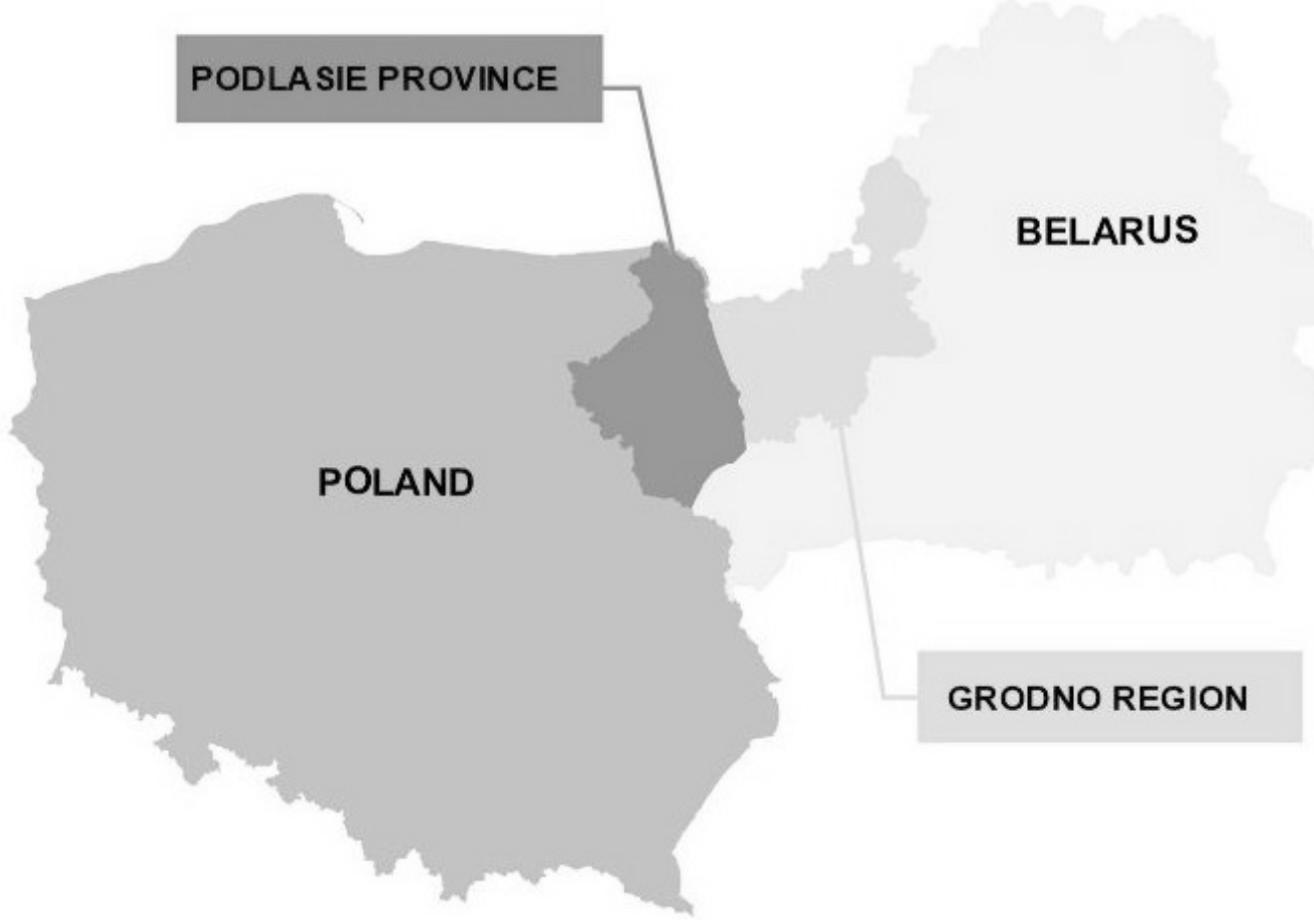

Figure 3. Location of Podlasie Province in Poland and Grodno Region in Belarus [11] 
Grodno Region covers a larger area than Podlasie Province (25 thousand sq km and 20 thousand sq km respectively); however, the population of the two analyzed regions is similar (Table 1). Podlasie Province is characterized by a higher percentage of people living in rural areas. Besides, large areas of both studied regions are covered by forests (including Bialowieża Primeval Forest). In Grodno Region, forest, wooded and forested land account for $38.1 \%$ of the total area, while in Podlasie Province $-31.8 \%$. The agricultural land in Podlasie Province accounts for $60.3 \%$ of the total area (in Grodno Region $-49.6 \%$ ). In both surveyed territories, agricultural land is dominated by arable land (from $59.9 \%$ to $67.8 \%$ ), while pasture accounts for $31.0 \%$ to $38.2 \%$ of the farmland. The most noticeable difference in regard to land use of the analyzed regions is wasteland, which in Grodno Region constitutes 6.4\% of the total area, while in Podlasie Province - 2.8\% [11]. The detailed data are presented in Table 1.

Table 1. Data of Grodno Region and Podlasie Province (as of 2012) [11]

\begin{tabular}{|c|c|c|c|c|c|}
\hline & & \multicolumn{2}{|c|}{ Grodno Region } & \multicolumn{2}{|c|}{ Podlasie Province } \\
\hline \multirow{4}{*}{ POPULATION } & Population total & \multicolumn{2}{|c|}{1058415} & \multicolumn{2}{|c|}{1198690} \\
\hline & City & 763574 & $72.1 \%$ & 723303 & $60.3 \%$ \\
\hline & Countryside & 294841 & $27.9 \%$ & 475387 & $39.7 \%$ \\
\hline & Population per 1 sq.km. & \multicolumn{2}{|c|}{42} & \multicolumn{2}{|c|}{59} \\
\hline \multirow{6}{*}{ LAND USE } & $\begin{array}{l}\text { Area } \\
\text { Total }\end{array}$ & \multicolumn{2}{|c|}{$25127 \mathrm{~km}^{2}$} & \multicolumn{2}{|c|}{$20187 \mathrm{~km}^{2}$} \\
\hline & Forest use & $12462 \mathrm{~km}^{2}$ & $49.6 \%$ & $12166 \mathrm{~km}^{2}$ & $60.3 \%$ \\
\hline & Forested, wooded and shrubbed land & $9567 \mathrm{~km}^{2}$ & $38.1 \%$ & $6423 \mathrm{~km}^{2}$ & $31.8 \%$ \\
\hline & Land under surface waters & $356 \mathrm{~km}^{2}$ & $1.4 \%$ & $275 \mathrm{~km}^{2}$ & $1.4 \%$ \\
\hline & Built-up and urbanized land & $1123 \mathrm{~km}^{2}$ & $4.5 \%$ & $740 \mathrm{~km}^{2}$ & $3.7 \%$ \\
\hline & Waste & $1619 \mathrm{~km}^{2}$ & $6.4 \%$ & $543 \mathrm{~km}^{2}$ & $2.8 \%$ \\
\hline \multirow{3}{*}{ FOREST GROUNDS } & Forest land area including forests & \multicolumn{2}{|c|}{$\begin{array}{l}978.2 \text { thou. ha } \\
\text { 873.4 thou. ha }\end{array}$} & \multicolumn{2}{|c|}{$\begin{array}{l}628.4 \text { thou. ha } \\
618.4 \text { thou. ha }\end{array}$} \\
\hline & Woodiness & \multicolumn{2}{|c|}{$34.8 \%$} & \multicolumn{2}{|c|}{$30.6 \%$} \\
\hline & Forest area per capita & \multicolumn{2}{|c|}{0.82 ha } & \multicolumn{2}{|c|}{0.52 ha } \\
\hline \multirow{3}{*}{ FARMLAND } & $\begin{array}{l}\text { Farmland } \\
\text { including: }\end{array}$ & \multicolumn{2}{|c|}{1246.2 thou. ha } & \multicolumn{2}{|c|}{ 1083.4 thou. ha } \\
\hline & Arable land & $\begin{array}{l}844.4 \text { thou. } \\
\text { ha }\end{array}$ & $67.8 \%$ & $\begin{array}{l}649.3 \text { thou. } \\
\text { ha }\end{array}$ & $59.9 \%$ \\
\hline & Meadows and pastures & $\begin{array}{l}386.2 \text { thou. } \\
\text { ha }\end{array}$ & $31.0 \%$ & $\begin{array}{l}413.7 \text { thou. } \\
\text { ha }\end{array}$ & $38.2 \%$ \\
\hline \multirow{6}{*}{ HEALTHCARE } & Number of physicians & \multicolumn{2}{|c|}{4640} & \multicolumn{2}{|c|}{2987} \\
\hline & Physicians per 10 thou. population & \multicolumn{2}{|c|}{43.8} & \multicolumn{2}{|c|}{24.9} \\
\hline & Outpatient health care facilities & \multicolumn{2}{|c|}{262} & \multicolumn{2}{|c|}{980} \\
\hline & $\begin{array}{l}\text { Population per } 1 \text { outpatient health care } \\
\text { facility }\end{array}$ & \multicolumn{2}{|c|}{4040} & \multicolumn{2}{|c|}{1223} \\
\hline & $\begin{array}{l}\text { Outpatient health advice throughout the } \\
\text { year (in thousands) }\end{array}$ & \multicolumn{2}{|c|}{14436.2} & \multicolumn{2}{|c|}{9745.1} \\
\hline & General hospitals & \multicolumn{2}{|c|}{85} & \multicolumn{2}{|c|}{33} \\
\hline
\end{tabular}

Grodno Region can boast of a far higher number of physicians while the number of inhabitants in both analyzed territories is similar. It also has many more hospitals. On the other hand, Podlasie Province has three times more outpatient health care facilities [11]. The detailed data are shown in Table 1.

\section{Surveillance Systems Organization in Poland and Belarus}

In Poland, Lyme borreliosis epidemiological surveillance was implemented in 1996. By 2004, notification of the disease was based on medical diagnosis and data. In many cases, the records relied on non-specific clinical 
symptoms, most often confirmed by positive screening results. In order to monitor the occurrence of the disease more accurately, a case definition was developed at the beginning of 2005, which facilitated routine epidemiological surveillance. This definition takes into account the results of the data analysis from epidemiological investigations and the case definitions adopted by the CDC in the USA and the European Union Concerted Action on Lyme Borreliosis (EUCALB) [12]. In Poland, the physician notifies the district public health authority after diagnosing the case. The district public health officers complete standardized case reports based on medical documentation and interview patient directly. Then, they send biweekly reports on the number of incidents to the provincial offices. These in turn send the reports aggregated at the regional level to the National Institute of Public Health National Institute of Hygiene in Warsaw (NIPH-NIH). Further, every 3 months, the district public health officers send individual case reports, which include demographic, clinical and epidemiological information to NIPH-NIH, where they are processed. Feedback on the incidence data is provided on the Institutes websites $[9,13]$.

According to the recommendations of the Polish Society of Epidemiology and Infectious Diseases, LB diagnosis should be based on the criteria among which the most important ones include a medical history of the tick bite and clinical symptoms. The laboratory diagnosis is based on a 'two-step diagnostic protocol', which consists of detection of specific antibodies, using an immunoenzymatic method and Western blot. It is recommended that, in order to detect DNA of $B$. burgdorferi spirochetes by PCR, skin samples with erythema migrans or acrodermatitis chronica atrophicans taken from limbs, synovial fluid and CSF should be used. It is not recommended to apply PCR using blood sample. A lack of standardization is a limitation of PCR in diagnosing LB [14].

Serological diagnosis is not significant in typical cases of erythema migrans, as the presence of a dermatological skin lesion and a medical history of the tick bite is sufficient to diagnose the disease. However, erythema over 5 $\mathrm{cm}$ in diameter is of diagnostic significance [14]. Depending on clinical symptoms, different laboratory tests are recommended, which are presented in Table 2.

Table 2. Laboratory tests recommended by the Polish Society of Epidemiology and Infectious Diseases in 2015 [14]

\begin{tabular}{|c|c|c|c|}
\hline \multicolumn{2}{|r|}{ Lyme borreliosis } & Laboratory testing & PCR \\
\hline \multirow{5}{*}{ 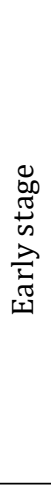 } & Erythema migrans & No serological testing is recommended & $\begin{array}{l}\text { Sample of skin from } \\
\text { a margin of erythema }\end{array}$ \\
\hline & $\begin{array}{c}\text { Borrelial } \\
\text { lymphoma }\end{array}$ & $\begin{array}{c}\text { ELISA } \\
\text { Detection of IgG and/or IgM }\end{array}$ & \\
\hline & Early neuroborreliosis & $\begin{array}{c}\text { Lymphocytic pleocytosis in CSF. } \\
\text { ELISA IgM and/or increased IgG titre in serum. } \\
\text { Intradural production of antibodies against } \\
\text { B. burgdorferi }\end{array}$ & Cerebrospinal fluid \\
\hline & Lyme carditis & $\begin{array}{c}\text { ELISA } \\
\text { IgM + IgG antibodies (increasing IgG titre) }\end{array}$ & \\
\hline & Lyme arthritis & $\begin{array}{c}\text { ELISA } \\
\text { IgM and/or increased IgG titre in serum }\end{array}$ & Synovial fluid \\
\hline \multirow{4}{*}{ 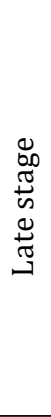 } & \multirow[t]{2}{*}{ Neuroborreliosis } & $\begin{array}{l}\text { ELISA } \\
\text { IgM and/or increased IgG titre in serum. } \\
\text { Intradural production of antibodies, } \\
\text { lymphocytic pleocytosis }\end{array}$ & Cerebrospinal fluid \\
\hline & & Peripheral polyneuropathies: IgG antibodies in serum & \\
\hline & Lyme arthritis & $\begin{array}{c}\text { ELISA } \\
\text { IgG antibodies in serum } \\
\end{array}$ & Synovial fluid \\
\hline & $\begin{array}{l}\text { Acrodermatitis } \\
\text { chronica } \\
\text { athrophicans }\end{array}$ & $\begin{array}{c}\text { ELISA } \\
\text { IgG antibodies in serum } \\
\text { Histopathological examination of skin sample }\end{array}$ & $\begin{array}{l}\text { Sample of changed } \\
\text { skin }\end{array}$ \\
\hline
\end{tabular}

The diagnostic standards for Lyme borreliosis in Belarus include:

- clinic symptoms of Lyme borreliosis;

- serologic testing - IgM and IgG in blood;

- PCR (blood, CSF) and other not special methods.

As a rule, Erythema migrans requires only a clinical diagnosis. Two types of serological tests (Enzyme immunoassay or immunofluorescence assay, in some cases Western blot testing) are used. PCR blood and CSF are applied only in some hospitals on an irregular basis $[15,16,17]$. The detailed diagnostic standards for Lyme borreliosis in Belarus are provided in Table 3. 
Table 3. Algorithm of the Lyme borreliosis diagnostic system in Belarus $[15,16,17]$

\begin{tabular}{|c|c|c|}
\hline $\begin{array}{l}\text { Early Lyme borreliosis } \\
\text { Erythema migrans }\end{array}$ & $\begin{array}{l}\text { Common blood analysis } \\
\text { Urinalysis } \\
\text { ECG } \\
\text { Serologic test for IgM and IgG } \\
\text { (use only in special situation) }\end{array}$ & $\begin{array}{l}\text { Biochemical blood test: AIAT, CPR, } \\
\text { bilirubin, glucose level } \\
\text { consultation of the neurologist, } \\
\text { consultation of the doctor dermato- } \\
\text { logist }\end{array}$ \\
\hline $\begin{array}{l}\text { Early neurologic Lyme borreliosis } \\
\text { (Lyme meningitis and other) }\end{array}$ & $\begin{array}{l}\text { Common blood analysis } \\
\text { urinalysis } \\
\text { ECG } \\
\text { Serologic test for IgM and IgG } \\
\text { LP and CSF analyse } \\
\text { consultation of the neurologist }\end{array}$ & $\begin{array}{l}\text { Biochemical blood test: AlAT, CPR, } \\
\text { bilirubin, glucose level } \\
\text { ophthalmological consultation }\end{array}$ \\
\hline $\begin{array}{l}\text { Late Lyme borreliosis } \\
\text { (Lyme carditis, } \\
\text { Lyme arthritis, } \\
\text { late neurologic Lyme borreliosis } \\
\text { and other) }\end{array}$ & $\begin{array}{l}\text { Common blood analysis } \\
\text { Urinalysis } \\
\text { ECG } \\
\text { Serologic test for IgM and IgG }\end{array}$ & $\begin{array}{l}\text { Biochemical blood test: AlAT, CPR, } \\
\text { bilirubin, glucose level } \\
\text { LP and CSF analysis } \\
\text { neurological consultation, cardiological } \\
\text { consultation, rheumatologic consultatior }\end{array}$ \\
\hline
\end{tabular}

\section{Recommendations for post-exposure prophylaxis}

In Poland, according to the recommendations of the Polish Society of Epidemiology and Infectious Diseases, prophylactic antibiotic treatment after a tick bite is not recommended. It should be considered in individual, special cases of multiple tick bites or when the person stays in the area which is considered endemic [14].

In Belarus, prevention of Lyme borreliosis after a recognized tick bite is routinely based on antimicrobial prophylaxis (used in the first 72 hours after the tick bite but only):

1. To adult patients Doxycycline ( $200 \mathrm{mg}$ once) and children $\geq 8$ years of age ( $4 \mathrm{mg} / \mathrm{kg}$ up to a maximum dose of $200 \mathrm{mg}$ )

2. To children $\leq 8$ years of age and pregnant women - Amoxicillin $500 \mathrm{mg} 3$ times a day (adult) and $50 \mathrm{mg} /$ kg per day in 3 divides doses (children) during 5 days.

3. In cases of allergy, when cefuroxime axetil can also be used.

The persons who have removed ticks attached to the skin are closely monitored for signs and symptoms of tick-borne diseases for up to 30 days - if they have followed prophylactic antibiotic treatment (ambulatory patients); those who do not use antimicrobial prophylaxis for various reasons are examined after 1,3 and 6 months (an ambulatory examination) $[15,16,17]$.

\section{Epidemiological situation of Lyme borreliosis in Podlasie Province and Grodno Region}

In the analysed five-year period (2012-2016), 968 Lyme borreliosis cases were recorded in Grodno Region, while in the neighbouring Podlasie Province the number was 6 times higher and amounted to 6197 cases. In both analyzed regions, Lyme borreliosis has recorded an increase (with a one-off decrease in 2015) over the past few years. The rate of incidence in Grodno Region has increased in this period from 15.1 to 25.0/100,000. Inhabitants, whereas in Podlasie Province from 81.4 to 134.9/100,000 residents [10,16-20] (Figures 4 and 5).

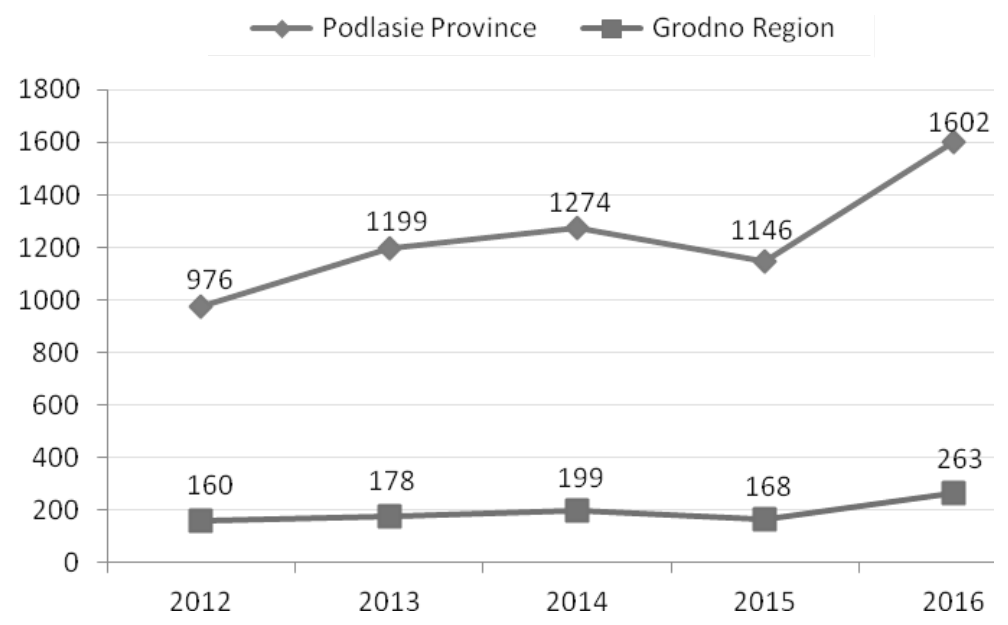

Figure 4. Number of Lyme borreliosis cases in Podlasie Province (Poland) and Grodno Region (Belarus) in the years 2012$2016[10,18-22]$ 


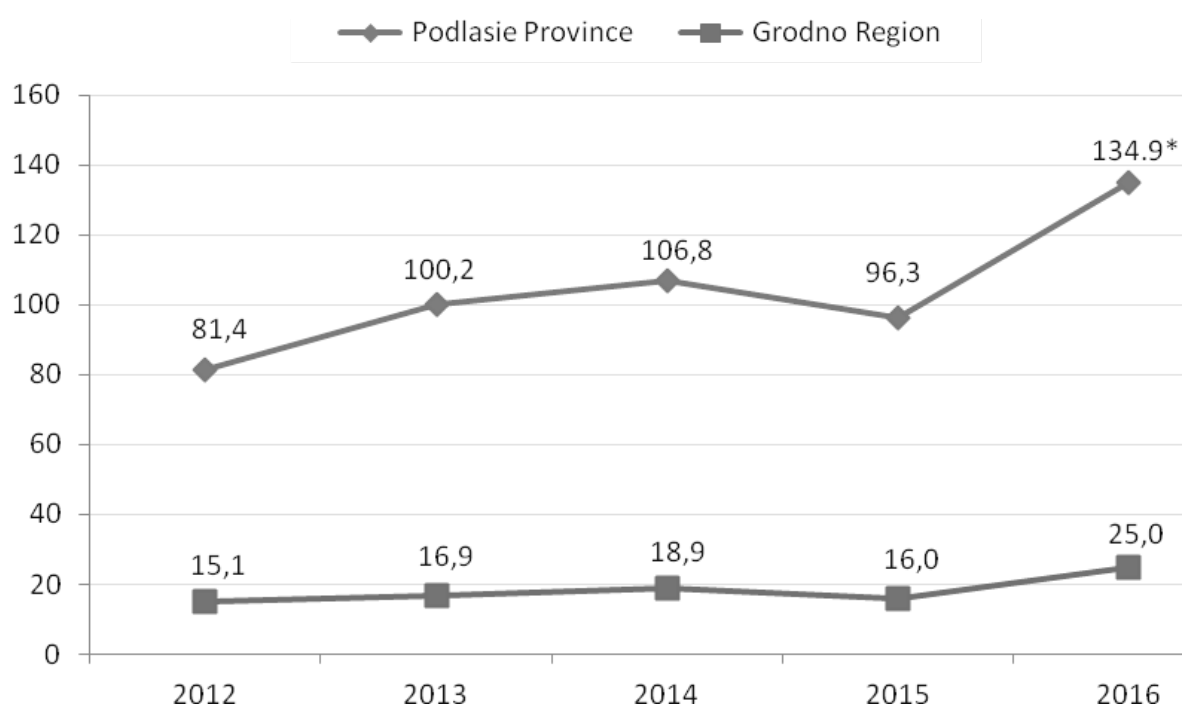

Figure 5. Lyme borreliosis incidence rate in Podlasie Province (Poland) and Grodno Region (Belarus) in the years 2012 $2016[10,18-22]$

In Grodno Region, the highest incidence of Lyme borreliosis in the analyzed period was recorded in 2016 in Volkovysk district (60.5/100,000 inhabitants). The districts in the Grodno Region which recorded higher rates of morbidity in each of the five analyzed years than the one shown in the index for the whole region, included: Volkovysk district, Schuchin district and Grodno city. None of the above districts borders directly with Poland; however, the city of Grodno, located near the border, is part of Grodno district, which borders with Poland (Podlasie Province). In the three districts of the Grodno Region that directly border with Podlasie Province, higher rates of morbidity were recorded only in some years and they were generally slightly higher than the overall incidence rate recorded for Grodno Region [10,18-22] (Table 4).

Table 4. Incidence rates of Lyme borreliosis (per 100,000 inhabitants) in districts adjacent to Grodno Region and Podlasie Province, 2012-2016 (the shaded area indicates morbidity rates which are higher than those for the region / province) [10,18-22]

\begin{tabular}{|c|c|c|c|c|c|c|}
\hline & & 2012 & 2013 & 2014 & 2015 & 2016 \\
\hline & & \multicolumn{5}{|c|}{ per 100,000 population } \\
\hline \multirow{4}{*}{ Grodno Region } & Grodno district & 11.9 & 16.0 & 20.1 & 10.0 & 20.0 \\
\hline & Grodno city & 18.7 & 21.4 & 27.9 & 24.5 & 26.2 \\
\hline & Berestovitsa district & 24.4 & 12.3 & 12.5 & 12.6 & 25.2 \\
\hline & Svisloch district & 5.8 & 29.4 & 6.0 & 24.7 & 30.8 \\
\hline \multicolumn{2}{|c|}{$\begin{array}{c}\text { Grodno Region } \\
\text { Total }\end{array}$} & 15.1 & 16.9 & 18.9 & 16.0 & 25.0 \\
\hline \multirow{4}{*}{ Podlasie Province } & Augustów district & 66.4 & 71.7 & 50.1 & 62.1 & 175.2 \\
\hline & Sokółka district & 117.0 & 173.0 & 184.2 & 126.2 & 209.8 \\
\hline & Białystok district & 63.6 & 76.3 & 84.2 & 75.2 & 119.8 \\
\hline & Hajnówka district & 154.9 & 165.3 & 197.9 & 167.3 & 338.1 \\
\hline \multicolumn{2}{|c|}{$\begin{array}{c}\text { Podlasie Province } \\
\text { Total }\end{array}$} & 81.4 & 100.2 & 106.8 & 96.3 & 134.9 \\
\hline
\end{tabular}

In Podlasie Province, the highest incidence rate of Lyme borreliosis in the analyzed period was recorded in 2013 in Sejny district (389.8/100,000 inhabitants). The districts in which the incidence rate was higher than that for the whole province in each consecutive year in the analysed period included: Suwałki, Sejny, Sokółka, Hajnówka and Bielsk Podlaski. Out of the five districts indicated above, four are border districts. Suwałki and Sejny border directly with Lithuania, while Sokółka and Hajnówka with Belarus (with Grodno Region) [10, 18-22]. The incidence rates for Lyme disease in Podlasie Province directly adjacent to Grodno Region are shown in Table 4. 


\section{Conclusion}

Both in Poland and Belarus an increase in Lyme disease incidence can be observed. The recorded incidence rates are however significantly higher in Poland than in Belarus (in 2016 they amounted to 55.2 and 19.7 per 100,000 inhabitants respectively) $[9,10]$. Due to such significant differences in the recorded cases, the epidemiological situation in the two neighbouring territories in the Polish-Belarusian border: Podlasie Province (located in the north-eastern part of Poland) and Grodno Region (north-western part of Belarus) was analyzed in the years 2012-2016.

The differences in the recorded morbidity for Lyme disease in the analyzed regions proved to be even greater than for the national indices in each of the five analyzed years. In 2016, the LB incidence rate in Grodno Region was 25.0/100,000 inhabitants, while in Podlasie Province it was over 5 times higher (134.9/100,000 inhabitants). The detailed analysis of the incidence rates in individual districts of the analyzed territories showed that, in Podlasie Province, it was the districts directly adjacent to Grodno Region that were characterized by high rates of Lyme disease. In the analyzed five-year period, two of them recorded higher incidence rates than the province index for the previous year. On the other hand, the districts of Grodno Region bordering with Podlasie Province generally recorded incidence rates close to the general index for Grodno Region [10,18-22].

The analyzed areas of the Polish-Belarusian border are similar in terms of number of inhabitants and share of agricultural and forest land in the total area of their territories (about 90\%). Podlasie Province is noted for its dominant share of agricultural land, while Grodno Region for its forests. Both areas feature high forest cover (from $30.6 \%$ to $34.8 \%$ ). The visible difference in the analyzed territories is the wasteland which prevails in Grodno Region. Another noticeable difference is a greater proportion of people living in rural areas in Podlasie Province [11], but this does not explain the large differences in the recorded LB incidence rates. These differences can arise from different systems of organization of medical services and their availability. Grodno Region can boast of a greater number of physicians and hospitals, but the number of ambulatory care facilities is much smaller [11], which may explain lower incidence of the disease in the areas distant from large urban centres. It is noteworthy that in Grodno city, in each of the five analyzed years, the rates of recorded morbidity were higher than those indicated in the index for entire Grodno Region.

The results of the analysis show a very large variation in the recorded incidence of Lyme borreliosis in neighbouring Polish-Belarusian border regions, which might be an indication that further detailed analysis is needed in order to identify the factors influencing such a situation.

\section{References:}

1. World Health Organization Regional Office for Europe. [cited 2017 Feb 10] Available from: http://www.euro. who.int/

2. Lindgren E, Jaenson TGT. Lyme borreliosis in Europe: influences of climate and climate change, epidemiology, ecology and adaptation measures. WHO Regional Office for Europe 2006. [cited 2017 Feb 16]. Available from: http://www.euro.who.int/__data/assets/pdf_file/0006/96819/E89522.pdf

3. Sykes RA, Makiello P. An estimate of Lyme borreliosis incidence in Western Europe. J Public Health (Oxf) 2017; 39(1): 74-81.

4. Wójcik-Fatla A, Szymańska J, Buczek A. Choroby przenoszone przez kleszcze. Część I. Ixodes ricinus jako rezerwuar i wektor patogenów. Zdrowie Publiczne. 2009; 119(2): 213-216 (in Polish).

5. Stefanoff P, Staszewska E, Ustrnul Z, Rogalska J, Łankiewicz A, Rosińska M. Badania ekologiczne ryzyka zachorowań na kleszczowe zapalenie mózgu w Polsce - omówienie metody. Przegl Epidemiol. $2008 ; 62$ suppl.: 112-121 (in Polish).

6. Rizzoli A, Hauffe HC, Carpi G, Vourc'h GI, Neteler M, Rosà R. Lyme borreliosis in Europe. Euro Surveill. 2011 [cited 2017 Feb 16]; 16(27): pii=19906. Available from: http://www.eurosurveillance.org/ViewArticle. aspx?ArticleId=19906

7. Kshirsagar DP, Ingale AM. Lyme disease: Emerging and re-emerging metazoonoses of global importance. Journal of Animal Research 2014; 4(1): 39-51.

8. Kmieciak W, Ciszewski M, Szewczyk EM. Tick-borne diseases in Poland: Prevalence and difficulties in diagnostics. Med Pr. 2016; 67(1): 73-87 (in Polish).

9. Smith R, Takkinen J. Lyme borreliosis: Europe-wide coordinated surveillance and action needed? Eurosurveillance 2006 [cited 2017 Feb 16]; 11(25): 2977. Available from: http://www.eurosurveillance.org/ ViewArticle.aspx?ArticleId $=2977$

10. The National Institute of Public Health-National Institute of Hygiene in Warsaw. [cited 2017 Jun 07]. Available from: http://www.pzh.gov.pl/ 
11. Data's from Grodno Regional Center of Hygiene, Epidemiology and Public Health.

12. Obwód grodzieński i województwo podlaskie w 2012 r. Urząd Statystyczny w Białymstoku. Białystok 2014 (in Polish).

13. Stefanoff P, Rosińska M, Zieliński A. Epidemiology of tick-borne diseases in Poland. Przegl Epidemiol. 2006; 60: 151-159 (in Polish).

14. Stefanoff P, Orlíková H, Príkazský V, Beneš Č, Rosińska M. Cross-border surveillance differences: tick-borne encephalitis and lyme borreliosis in the Czech Republic and Poland, 1999-2008. Cent Eur J Public Health. 2014; 22(1): 54-59.

15. Pancewicz SA, Garlicki AM, Moniuszko-Malinowska A, Zajkowska J, Kondrusik M, Grygorczuk S, et al. Diagnosis and treatment of tick-borne diseases recommendations of the Polish Society of Epidemiology and Infectious Diseases. Przegl Epidemiol. 2015; 69: 309-316.

16. The order of Ministry of Health of the Republic of Belarus No. 338 from 19.04.2016. About the prevention of diseases transmitted by ticks.

17. The resolution of the Ministry of Health of the Republic of Belarus No. 192 from 7.12.2012. Requirements for the organization and carrying out sanitary-antiepidemic actions directed on prophylaxis of diseases transmitted by ticks.

18. Appendix No. 1 to Order of Ministry of Health of the Republic of Belarus No. 961 from 24.08.2012. Clinical protocols of diagnostics and treatment of children with infectious diseases while providing medical assistance in outpatient and inpatient settings at the district, regional and national health organizations of the Republic of Belarus.

19. Ocena stanu sanitarnego województwa podlaskiego za 2012 rok. Państwowa Inspekcja Sanitarna Województwa Podlaskiego, Białystok, 2013 (in Polish).

20. Ocena stanu sanitarnego województwa podlaskiego za 2013 rok. Państwowa Inspekcja Sanitarna Województwa Podlaskiego, Białystok, 2014 (in Polish).

21. Ocena stanu sanitarnego województwa podlaskiego za 2014 rok. Państwowa Inspekcja Sanitarna Województwa Podlaskiego, Białystok, 2015 (in Polish).

22. Ocena stanu sanitarnego województwa podlaskiego za 2015 rok. Państwowa Inspekcja Sanitarna Województwa Podlaskiego, Białystok, 2016 (in Polish).

23. Ocena stanu sanitarnego województwa podlaskiego za 2016 rok. Państwowa Inspekcja Sanitarna Województwa Podlaskiego, Białystok, 2017 (in Polish). 